\title{
Epidermal growth factor-induced neuroendocrine differentiation and apoptotic resistance of androgen-independent human prostate cancer cells
}

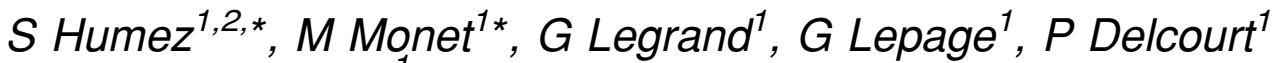 \\ and $N$ Prevarskaya ${ }^{1}$
}

\author{
${ }^{1}$ Laboratoire de Physiologie Cellulaire, INSERM EMI 0228, USTL, Bat. SN3, 59655 Villeneuve d'Ascq Cedex, France \\ ${ }^{2}$ Université d'Artois, Faculté des Sciences Jean Perrin, 62300 Lens, France \\ (Requests for offprints should be addressed to Shumez; Email: sandrine.humez@univ-lille1.fr) \\ *(S Humez and M Monet contributed equally to this work)
}

\begin{abstract}
Neuroendocrine differentiation (NED) has been implicated in prostate cancer progression and hormone-therapy failure. Neuroendocrine cells are non-proliferating and escape apoptotic cell death, although their origin and the causes of their apoptotic resistance have as yet been poorly elucidated. This study demonstrates a new mechanism involved in controlling NED. We report that epidermal growth factor $(5-50 \mathrm{ng} / \mathrm{ml})$ promotes neuroendocrine-like differentiation of androgenindependent DU145 prostate cancer cells. This differentiation is associated with an increase in the expression of Neuron Specific Enolase (NSE) and a reduction in cell proliferation and is blocked by inhibiting tyrosine kinase activity with genistein and with compound 56 (C56). An increase in the cAMP level, using dibutryl cAMP (db-cAMP) $(1 \mathrm{mM})$ and isobutylmethylxanthine $(100 \mu \mathrm{M})$, does not promote NED by itself, but does increase the effect of EGF on NED. In addition, EGF-induced NED protects cells from apoptosis induced with thapsigargin $(1 \mu \mathrm{M})$ by reducing the thapsigargin-induced cytosolic calcium overload. In order to describe how EGF-induced NED protects cells against thapigargin-induced calcium overload we investigated the spatiotemporal calcium signalling linked to apoptosis. By using thapsigargin in various conditions on DU145 cells and using microfluorimetric calcium measurements, we show that depletion of intracellular calcium store induces apoptosis and that the amplitude and duration of the capacitive calcium entry are two apoptosismodulating parameters. We show that protection against thapsigargin-induced apoptosis conferred by NED is achieved by reducing the amount and the speed of calcium that can be released from calcium pools, as well as modulating the amplitude of the subsequent calcium entry.
\end{abstract}

Endocrine-Related Cancer (2006) 13 181-195

\section{Introduction}

Prostate cancer (PC) is the second greatest cause of cancer-related death in many countries and in northern Europe it has already taken the number one position as the main cause of male cancer-related death (Landis et al. 1998). Androgen ablation is initially beneficial to nearly all men with PC, since androgen-dependent PC undergoes apoptotic death by such treatment (Kyprianou et al.
1990). Unfortunately, androgen ablation is only palliative and patients relapse into androgen-independent $\mathrm{PC}$, with dramatic consequences (Crawford 1989). Indeed, androgen-independent PC cells do not enter the programmed cell death pathway following androgen ablation (Denmeade et al. 1996). Neuroendocrine cells are one of the phenotypes of apoptosis-resistant cells. The frequency of neuroendocrine cells correlates with tumour malignancy, loss of androgen sensitivity and poor 
prognosis (Cussenot et al. 1998, Jongsma et al. 1999). In addition, significant and clustered neuroendocrine differentiation (NED) in PC can lead to an increase in proliferation and earlier tumour progression (Grobholz et al. 2005). Tumours with an increased neuroendocrine cell population are often more aggressive and eventually become androgen-independent (Abrahamsson 1999). However the molecular and cellular mechanisms controlling NED and the apoptosis resistance of neuroendocrine cells are only partially understood and improvement in our understanding of the biological nature of neuroendocrine cells is urgently required (Vashchenko \& Abrahamsson 2005).

According to the existing hypotheses, neuroendocrine cells are either derived from undifferentiated basal cells of the prostatic epithelium or have a neurogenic origin (Aumuller et al. 1999, Bonkhoff \& Remberger 1996). It is also described that PC cells themselves have the ability to transdifferentiate into cells with a neuroendocrine-like phenotype. This transdifferentiation generally occurs from androgendependent PC cells and is induced when cells are cultured with pharmacological agents that increase the intracellular level of cAMP, in the presence of interleukin or in a steroid-free medium (Bang et al. 1994, Burchardt et al. 1999, Cox et al. 2000, Mori et al. 1999, Zelivianski et al. 2001). Neuroendocrine cells represent an androgen-insensitive cell phenotype in the prostate (Krijnen et al. 1993). So, one may postulate that neuroendocrine cells could originate from a population of androgen-independent cancer cells, but this hypothesis remains to be proved.

Over the last 20 years, the ever-expanding pool of knowledge of growth factor-regulated pathways and their role in the pathogenesis of PC has been translated into rationally designed drug therapy (Barton et al. 2001). Epidermal growth factor (EGF) is known to have anti-apoptotic properties in numerous cell types including prostate cells (Mimeault et al. 2003). In addition to the well-described effect of growth factors in PC cells, it has been recently shown that heparinbinding EGF-like growth factor was able to induce transdifferentiation in LNCaP cells (Kim et al. 2002).

In an effort to understand how neuroendocrine cells progressively emerge in prostate malignancies and their relationship to hormone-refractory prostate carcinoma, we studied the EGF effect on transdifferentiation of androgen-independent DU145 cells.

In this study we show that EGF mediates NED in androgen-independent PC cells. This differentiation is linked to an increase in Neuron Specific Enolase (NSE) expression, reduction in cell growth and to a resistance to apotosis induced by thapsigargin (TG).
We also investigated the mechanisms involved in calcium-induced apoptosis in non-differentiated DU145 cells and we elucidated the mechanism by which EGF-induced NED renders neuroendocrine cells resistant to apoptosis induced by calcium overload. We show that in non-differentiated DU145 cells apoptosis may be induced by $\mathrm{Ca}^{2+}$-pool depletion alone and is amplified by extracellular $\mathrm{Ca}^{2+}$ entry. Our observations also reveal that apoptosis resistance of EGF-differentiated PC cells following TG exposure occurs via a reduction of both the amount of $\mathrm{Ca}^{2+}$ that can be released from $\mathrm{Ca}^{2+}$ pools and the amplitude of the subsequent $\mathrm{Ca}^{2+}$ entry. Moreover, we show for the first time that EGF-induced differentiation of DU145 cells is a mechanism that can increase the number of apoptosisresistant cells in PC. This latter result also strengthens the evidence for the existence of a common mechanism centred on a depression of the calcium signal linked to apoptotic resistance in PC.

\section{Experimental procedures}

\section{Cell culture}

The androgen-independent human PC cell line DU145, obtained from the American Type Culture Collection, was maintained in culture as previously described (Humez et al. 2004a). Prior to fluorescence measurements, the cells were trypsinized and transferred to glass coverslips. Cells were used 1-4 days after trypsinization.

\section{Measurement of in vitro cell growth}

Cells were seeded at an initial density of 500 cells/well in 96-well plates (Poly Labo, Strasbourg, France). After $48 \mathrm{~h}$, cells were cultured in treatment media (day 0 ). From day 0 , the treatment medium was changed daily for each condition. Cells were harvested on day 2. The CellTiter 96 Aqueous Non radioactive Cell Proliferation Assay (Promega Corp., Madison, WI, USA) was used to determine the number of viable cells (Humez et al. 2004a).

\section{Apoptosis assays with Hoechst staining}

The level of apoptosis was estimated from the number of apoptotic bodies visualized by Hoechst staining. The percentage of apoptotic cells was determined by counting at least 500 cells in random fields. The detailed procedure has been described previously (Humez et al. 2004b). The percentages of apoptotic cells presented in Figs 4 and 5 (see below) are representative of three independent experiments. 


\section{Analysis of cell cycle and apoptotis}

Flow cytometry was used to analyse the cell cycle and apoptosis, as previously described (Zamzami et al. 1995). Cells were fixed overnight at $4{ }^{\circ} \mathrm{C}$ with $70 \%$ icecold ethanol/PBS followed by propidium iodide $(50 \mu \mathrm{g} /$ $\mathrm{ml}$ ) staining and analysed in a Coulter xL cytofluorometer. Cell-cycle compartments were deconvoluted from a single-parameter DNA histogram of 30000 events using the WINCYCLE 32 program (Phoenix Flow Systems, San Diego, CA, USA) after the exclusion of cell doublets. The results were expressed as percentages of the cell population. A significant proportion of apoptotic cells were lost due to the repeated washing procedures, so the apoptosis measured with flow cytometry was therefore underestimated.

\section{$\mathrm{Ca}^{2+}$ measurements}

For cytosolic calcium measurement, fluorescence measurements were conducted on fura 2 acetoxymethyl ester (fura 2/AM; $5 \mu \mathrm{M}$ )-loaded (45 min) DU145 cells using a photomultiplier-based system (Photon Technologies, Princeton, NJ, USA) and a double-wavelength ( 340 and $380 \mathrm{nM}$ ) excitation protocol to quantify the absolute value of calcium concentration (Grynkiewicz et al. 1985). Direct quantification of $\mathrm{Ca}^{2+}$ within the endoplasmic reticulum (ER) $\left[\mathrm{Ca}^{2+}\right]_{\mathrm{ER}}$, was conducted in DU145 cells loaded (45 min) with the AM-ester derivative of Mag-fura 2 $(2 \mu \mathrm{M})$ as previously described (Humez et al. 2004b).

\section{Western blotting}

Western-blot analysis of protein expression was carried out as previously described (Humez et al. 2004b). AntiNSE antibody was from Dako, Trappes, France. Antiactin antibody was from Sigma, France.

\section{Data analysis}

Results were expressed as means \pm s.E.M. except when indicated in the figure legend. Plots were produced using Origin 5.0 (Microcal Software Inc., Northampton, MA, USA). Each experiment was repeated at least three times. The Tukey-Kramer test was used for statistical comparison among means and differences and $P<0.05$ was considered significant.

\section{Results}

\section{EGF induces NED of DU145 cells}

The effect of EGF on DU145 cell morphology was examined. When DU145 cells were cultured in a medium containing 10 or $2 \%$ foetal calf serum (FCS), their growth plate, by forming colonies in which cells were rounded, was in close association and did not exhibit any processes (Fig. 1a and b). From time to time, isolated cells showing short processes and oval cell bodies, which look like differentiated cells, were observed and represented about $5 \%$ of the cells. Following treatment with EGF for 3 days $(5 \mathrm{ng} / \mathrm{ml})$, morphological changes appeared. Figure 1c shows that treatment of DU145 with EGF resulted in a significant level of morphological differentiation as shown by the appearance of neuritic-like extensions that often possessed growth cone-like structures. In addition, EGF-treated DU145 cells are individualized and did not form clusters, as is usually observed (Fig. 1a and b). These morphological changes were similar to descriptions of PC cells undergoing differentiation towards neuroendocrine phenotypes (Bang et al. 1994). The proportion of neuroendocrine-like cells observed after a 3-day EGF treatment was $35 \pm 4.7 \%(n=3)$.

To evaluate NED more objectively, expression of NSE was examined by western blotting. This marker has been used previously to assess the extent of differentiation in LNCaP cells (Mori et al. 1999, Vanoverberghe et al. 2004). As shown by Fig. 1d, NSE expression dramatically increased when cells were treated with EGF as compared with cells cultured with $2 \%$ FCS. In addition Fig. 1d also shows that NSE expression was higher when cells were cultured with $10 \%$ FCS rather than when they were cultured with $2 \%$ FCS. As depicted in Fig. 1f, morphological differentiation was time- and dose-dependent. The morphological differentiation induced by EGF $(5 \mathrm{ng} /$ $\mathrm{ml}$ ), estimated by counting morphologically differentiated cells, increased with time and reached a plateau after 3 days of culture. Increasing the dose of EGF significantly increased the level of morphological differentiation in a dose-dependent manner that reached $63 \%$ of the cell population when $50 \mathrm{ng} / \mathrm{ml}$ EGF was applied. In addition, increasing doses of EGF also augmented NSE expression (Fig. 1g).

A direct correlation has previously been demonstrated between NED of LNCaP cells and inhibition of mitotic activity (Burchardt et al. 1999). We therefore used a cell-proliferation assay to determine the number of viable cells and to measure mitotic activity of DU145 cells treated with EGF. Relative to untreated cells, the mitotic activity of EGF-treated cells was significantly reduced with maximum mitotic activity reduction of about $20 \%$, when cells were treated with EGF from 1.6 to $6.2 \mathrm{ng} / \mathrm{ml}$ (Fig. 1e). When EGF was used at higher concentrations (up to $12.5 \mathrm{ng} / \mathrm{ml}$ ) it had no significant effect on cell growth. In addition, 
a

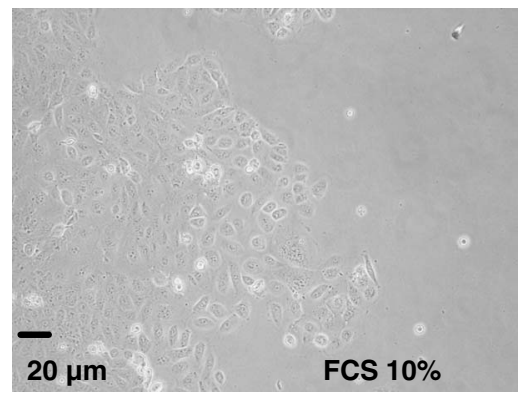

d

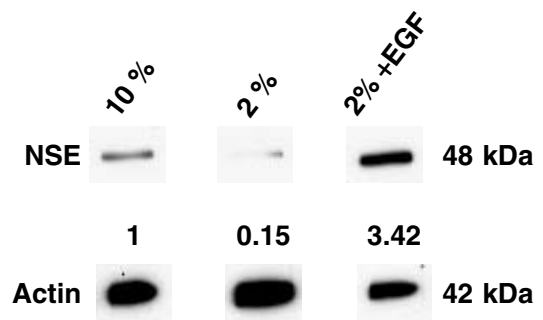

f

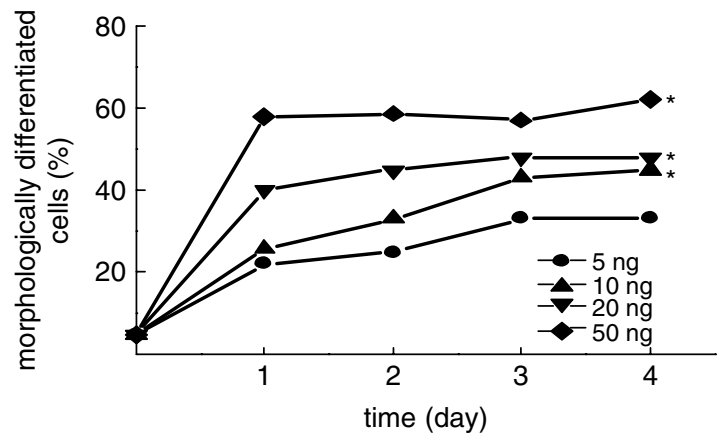

b

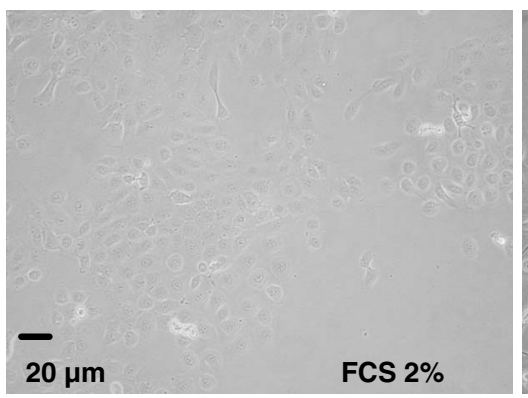

c

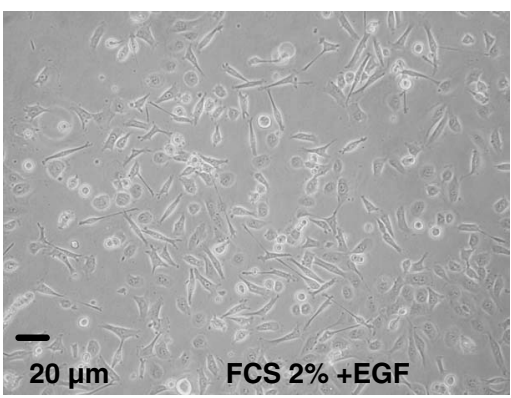

e

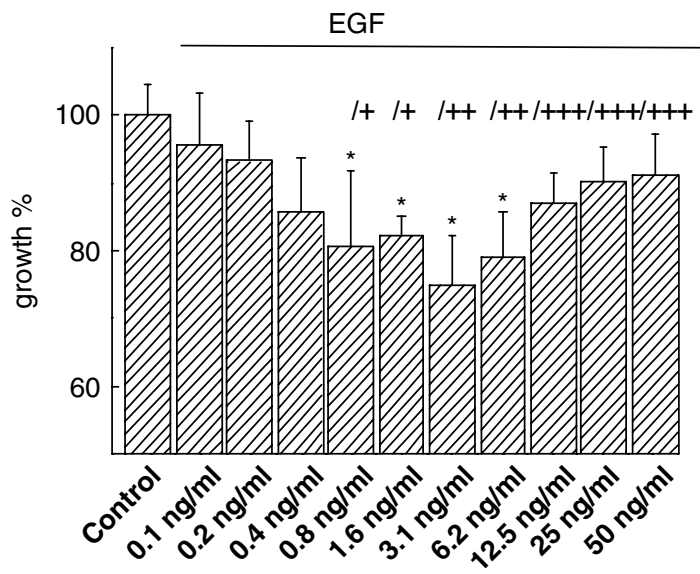

g

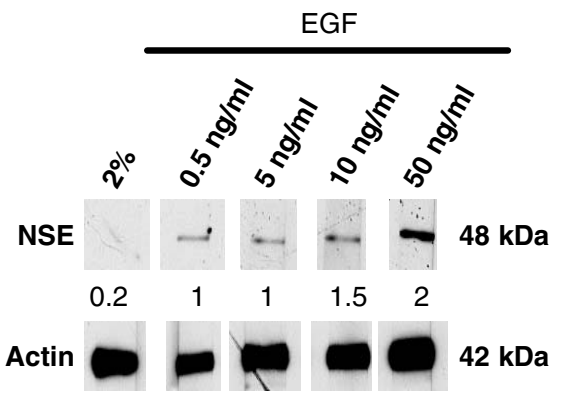

Figure 1 EGF effects on cell morphology and on expression of NSE in human PC DU145 cells. Cells were cultured in media supplemented with $10 \%$ FCS. On the following day, the medium was replaced by a medium containing $2 \%$ serum supplemented with EGF. Cells were treated for 3 days in these conditions. The medium was renewed daily. (a-d) EGF induces morphological differentiation of DU145 cells. DU145 cells were maintained for $72 \mathrm{~h}$ in a medium containing (a) $10 \%$ FCS, (b) $2 \%$ FCS, (c) $2 \%$ FCS and $5 \mathrm{ng} / \mathrm{ml}$ EGF. (d) EGF increases the expression of the neuroendocrine marker, NSE. Semi-quantitative Western blot after $30 \mu \mathrm{g}$ per well of total protein extraction for the conditions presented in $(\mathrm{a}-\mathrm{c})$. Actin expression was used as a control to compare NSE expression between different experimental conditions. (e) EGF reduces cell growth. Cell growth measured after 3 days of treatment with EGF from 0.1 to $50 \mathrm{ng} / \mathrm{ml}$ compared with non-treated cells (control). Morphological differentiation: 10-30\% (+); 30-40\% $(++)$; $\leq 40 \%(+++)$. Results are expressed as means \pm s.D. (f) EGF induces morphological differentiation of DU145 cells in a time- and dose-dependent manner. Cells were cultured from 1 to 4 days with $5,10,20$ or $50 \mathrm{ng} / \mathrm{ml}$ EGF. Morphological differentiation was determined after counting morphologically differentiated cells. (g) Semiquantitative western blot after $30 \mu \mathrm{g}$ per well of total protein extraction for the conditions presented after $72 \mathrm{~h}$ incubation with increasing doses of EGF. 
A

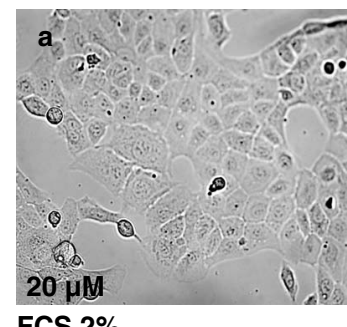

FCS $2 \%$

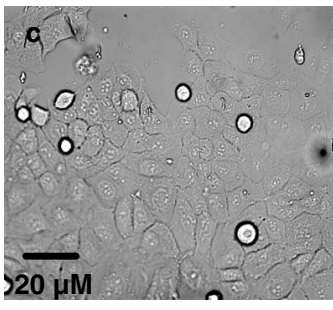

FCS $2 \%$ + genistein

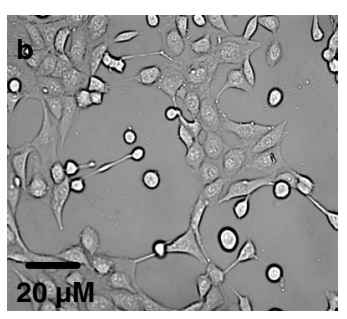

FCS2\%+ EGF

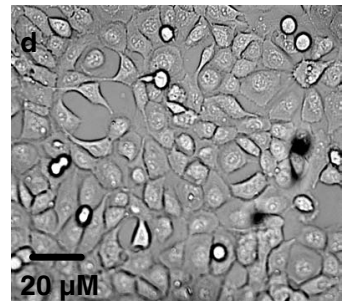

FCS 2\%+ EGF + genistein
C

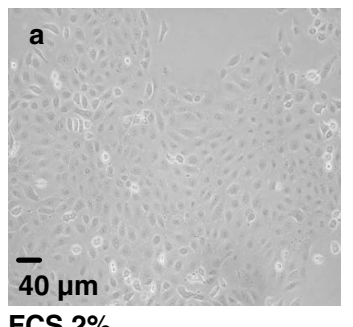

FCS 2\%

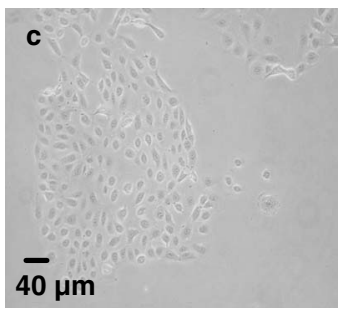

FCS $2 \%+C 56$

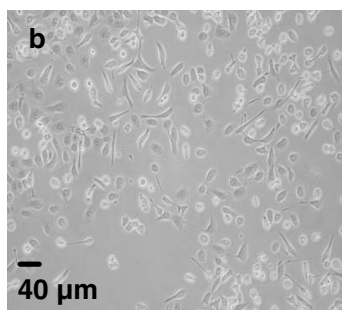

FCS 2\%+EGF

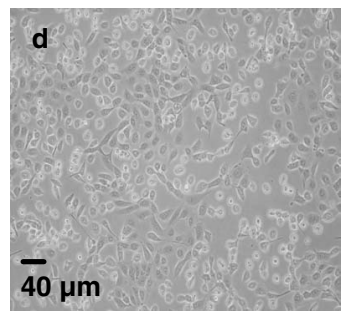

FCS $2 \%+E G F+C 56$
B

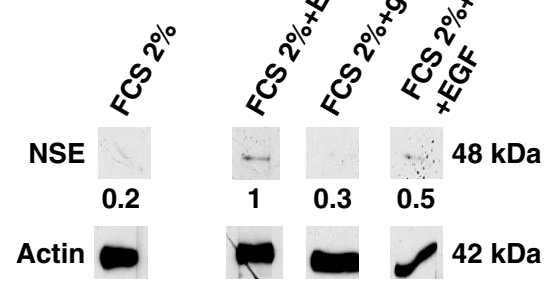

D

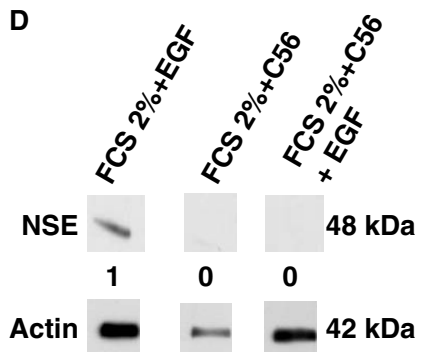

Figure 2 Morphological differentiation induced by EGF was reduced following inhibition of tyrosine kinase activity with genistein (gen) and following inhibition of EGF receptors with C56. (A) Cells were cultured in media supplemented with $10 \%$ FCS. On the following day, the medium was replaced by a medium containing (a) $2 \%$ serum supplemented with (b) $5 \mathrm{ng} / \mathrm{ml}$, (c) $10 \mu \mathrm{M}$ genistein or (d) both. Cells were treated with for 3 days in these conditions. The medium was renewed daily. (B) Semi-quantitative Western blot after $30 \mu \mathrm{g}$ per well of total protein extraction for the conditions in (A). (C) Cells were cultured in media supplemented with $10 \%$ FCS. On the following day, the medium was replaced by a medium containing (a) $2 \%$ serum supplemented with (b) $5 \mathrm{ng} / \mathrm{ml}$ EGF, (c) 15 pM C56 or (d) both. Cells were treated with for 3 days in these conditions. The medium was renewed daily. (D) Semiquantitative Western blot after $30 \mu \mathrm{g}$ per well of total protein extraction for the conditions presented from (C). Actin expression was assessed to compare NSE expression to that of actin between different experimental conditions.

treatment of DU145 cells with EGF from 0.8 to $50 \mathrm{ng} / \mathrm{ml} \mathrm{lead} \mathrm{to} \mathrm{morphological} \mathrm{differentiation} \mathrm{in} \mathrm{a}$ dose-dependent manner.

As depicted by Fig. 2A and B, the differentiation induced by EGF was blocked when cells were treated with genistein, a specific inhibitor of tyrosine autophosphorylation of the EGF receptor. When cells were cultured with EGF $(5 \mathrm{ng} / \mathrm{ml})$ and genistein $(10 \mu \mathrm{M})$, the rate of differentiation was 2-fold less than the rate of differentiation observed when cells were treated with EGF alone. In effect, the rate of differentiation was $31.4 \pm 4 \%(n=6)$ when cells were treated with EGF whereas it was $15.8 \pm 5.3(n=6)$ when EGF was added with genistein. In addition, the NSE expression was reduced. The differentiation induced by EGF was also blocked when cells were treated with C56, a specific inhibitor of the EGF receptor (Fig. 2C and D). When cells were cultured with EGF $(5 \mathrm{ng} / \mathrm{ml})$ and C56 $(15 \mathrm{pM})$ the rate of differentiation was $50 \%$ less than that observed when cells were treated with EGF alone and NSE expression was inhibited.

\section{Increase in cAMP level enhances EGF-induced NED of DU145 cells}

It has been well described that cAMP-dependent protein kinase (PKA) plays a central role in the acquisition of NED observed in LNCaP cells (Burchardt et al. 1999, Cox et al. 2000, Mariot et al. 2002). It has also been clearly described that activation of cAMP-dependent 


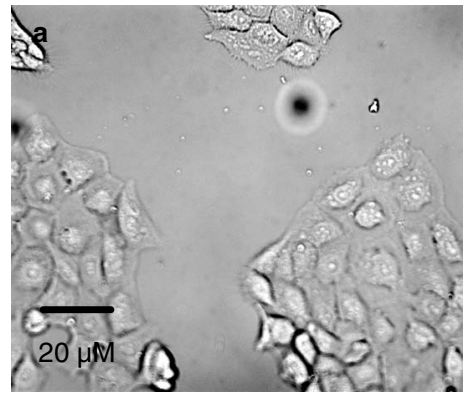

FCS $2 \%$

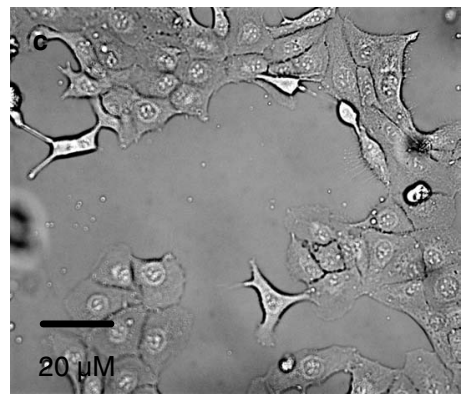

FCS $2 \%+d b-c y c l i c ~ A M P+I B M X$

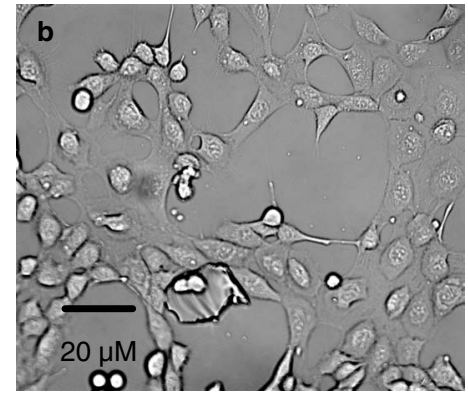

FCS $2 \%+E G F$

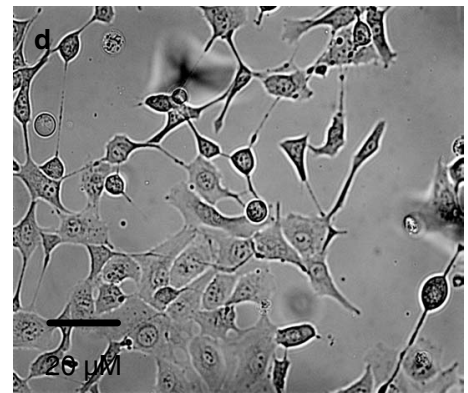

FCS $2 \%+d b$-cyclic AMP+IBMX+EGF

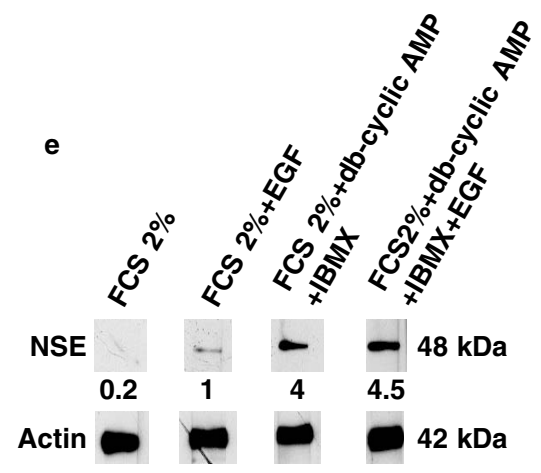

Figure 3 Increase in intracellular cAMP does not cause morphological differentiation but enhances morphological differentiation induced by EGF. Cells were cultured in media supplemented with $10 \%$ FCS. On the following day, the medium was replaced by a medium containing (a) $2 \%$ serum supplemented with (b) $5 \mathrm{ng} / \mathrm{ml} E G F$, (c) $1 \mathrm{mM} \mathrm{db}-\mathrm{cAMP}$ and $100 \mu \mathrm{M}$ IMBX or (d) db-cAMP, IMBX and EGF. Cells were treated for 3 days in these conditions. The medium was renewed daily. (e) Semi-quantitative western blot after $30 \mu \mathrm{g}$ per well of total protein extraction for the conditions in $(\mathrm{a}-\mathrm{e})$. Actin expression was assessed as a control to compare NSE expression between different experimental conditions.

protein kinase is both necessary and sufficient for stimulation of certain neuroendocrine characteristics by adenylate cyclase activators (Cox et al. 2000). Thus, we first tested the effect of increasing cAMP level on DU145 cell morphology (Fig. 3a-d). When DU145 cells were treated with dibutryl cAMP (db-cAMP; $1 \mathrm{mM}$ ) and isobutylmethylxanthine (IBMX; $100 \mu \mathrm{M}$ ), only a few cells acquired a neuroendocrine morphology. In effect, the amount of cells that had a neuroendocrine phenotype was $5.0 \pm 3.0 \%(n=6)$ in the presence of agents that increase the cAMP level and was $2.0 \pm 3.2 \%$ $(n=6)$ in control conditions (Fig. 3a and c). However, treatment with db-cAMP and IBMX significantly increased the rate of morphologically observed NED induced by EGF $(5 \mathrm{ng} / \mathrm{ml})$. The rate of NED observed when cells were treated with EGF $(5 \mathrm{ng} / \mathrm{ml})$ was $31.0 \pm 3.1 \% \quad(n=6) \quad$ compared with $44.2 \pm 3.2 \%$ $(n=6)$ when db-cAMP and IBMX were added to EGF (Fig. 3b and d). Interestingly, when DU145 cells were treated with db-cAMP $(1 \mathrm{mM})$ and IBMX $(100 \mu \mathrm{M})$, NSE expression was significantly raised compared with untreated cells. Furthermore, the 
addition of EGF on cells treated with db-AMP and IBMX was not able to increase NSE expression compared with that observed with db-cAMP and IBMX alone. These latter results indicate (i) that db-cAMP and IBMX promote NSE expression without achieving morphological differentiation, (ii) that EGF is able to enhance NED following db-cAMP and IBMX exposure and (iii) that EGF is able to promote NSE expression and morphological differentiation.

\section{EGF-induced NED protects DU145 cells from the TG-induced apoptosis}

As it has been established that NED protects LNCaP cells from apoptosis (Vanoverberghe et al. 2004), we went on to investigate the effect of EGF on apoptosis induced by calcium overload. For this we used TG, which causes a strong calcium increase, and induces apoptosis in DU145 cells (He et al. 2002). Our experiments show that $72-\mathrm{h}$ pretreatment with $5 \mathrm{ng} / \mathrm{ml}$ EGF before a 48 -h treatment with $1 \mu \mathrm{M}$ TG reduced the level of TG-induced apoptosis (assessed by Hoecht staining) by $50 \%$. Indeed, in these conditions, the apoptosis level of neuroendocrine-differentiated cells was $6 \%$ whereas it reached $12 \%$ when cells were kept in a non-differentiated state (Fig. 4A). The resistance of apoptosis conferred by NED was also detected by flow cytometry (Fig. 4B).

We then investigated whether EGF-induced NED was able to affect the TG-induced calcium overload. Our experiments demonstrate that NED stably reduced the basal intracellular calcium concentration $\left(\left[\mathrm{Ca}^{2+}\right]_{\mathrm{i}}\right)$ measured after a $48 \mathrm{~h}$ TG exposure (Fig. $4 \mathrm{C}$ ). Indeed, when cells were exposed to TG for $48 \mathrm{~h}$, $\left[\mathrm{Ca}^{2+}\right]_{\mathrm{i}}$ reached $206 \pm 12 \mathrm{nM}(n=113)$. However, in neuroendocrine-differentiated cells $\left[\mathrm{Ca}^{2+}\right]_{\mathrm{i}}$ rose to $88 \pm 3 \mathrm{nM}(n=73$; Fig. $4 \mathrm{C})$. In addition, as depicted in Fig. 4D the protection from the calcium overload induced by NED was abolished when the EGF receptors were blocked with C56 (15 pM).

\section{Mechanisms of $\mathrm{Ca}^{2+}$ homeostasis involved in apoptosis induction in androgen- independent PC DU145 cells}

To understand the mechanisms that lead EGF to induce a protective effect from calcium-induced apoptosis we studied the spatiotemporal calcium signalling leading to apoptosis in DU145 cells. With this aim, we treated cells with $1 \mu \mathrm{M}$ TG in various extracellular conditions (Fig. 5). Sarcoplasmic/endoplasmic-reticulum $\mathrm{Ca}^{2+}$-ATPase inhibition by TG generally results in a biphasic increase in $\left[\mathrm{Ca}^{2+}\right]_{i}$, reflecting a passive $\mathrm{Ca}^{2+}$ release through endoplasmic reticulum leak channels, followed by a capacitative $\mathrm{Ca}^{2+}$ entry through plasma membrane $\mathrm{Ca}^{2+}$ channels activated by store depletion. In a $\mathrm{Ca}^{2+}$-free medium, a 48 -h treatment by TG $(1 \mu \mathrm{M})$ induced only a short, transient increase in $\left[\mathrm{Ca}^{2+}\right]_{i}$ (at the time of TG application) due to $\mathrm{Ca}^{2+}$ store mobilization (see trace in Fig. 5a). Such a treatment induces apoptosis in $5.2 \%$ of cells in $48 \mathrm{~h}$. In cells treated with the $\mathrm{Ca}^{2+}$ chelator $50 \mu \mathrm{M}$ BAPTA-AM (bis-(o-aminophenoxy)ethane- $N, N, N^{\prime}, N^{\prime}$-tetra-acetic acid tetrakis(acetoxymethyl ester)) in a $\mathrm{Ca}^{2+}$-free medium (Fig. 5b), TG induced the emptying of $\mathrm{Ca}^{2+}$ stores, but without any increase in free $\left[\mathrm{Ca}^{2+}\right]_{\mathrm{i}}$. In these conditions, TG also induced apoptosis in $5 \%$ of cells. Note that a 48-h treatment in a $\mathrm{Ca}^{2+}$-free medium supplemented with $50 \mu \mathrm{M}$ BAPTA-AM alone (without TG) did not induce apoptosis (data not shown). Thus, independently of the cytosolic $\mathrm{Ca}^{2+}$ level, the mobilization of $\mathrm{Ca}^{2+}$ stores induced apoptosis in $5 \pm 1 \%(n=3)$ of DU145 cells.

In order to evaluate the role of cytosolic increase in $\mathrm{Ca}^{2+}$ in the induction of apoptosis in these cells, apoptosis was measured after treating DU145 cells in a medium which contained $2 \mathrm{mM} \mathrm{Ca}^{2+}$. Indeed, readmitting $2 \mathrm{mM} \mathrm{Ca}^{2+}$ into the extracellular medium after the transient increase in $\mathrm{Ca}^{2+}$-free medium caused by TG $(1 \mu \mathrm{M})$, induced capacitive calcium entry (see trace in Fig. $5 \mathrm{c}$ ), causing in sustained increase in $\left[\mathrm{Ca}^{2+}\right]_{\mathrm{i}}$ (see the table in Fig. 5c, after 24 and $48 \mathrm{~h}$ of treatment). In these conditions, when $\mathrm{Ca}^{2+}$ is stably raised for $48 \mathrm{~h}$, apoptosis is induced in $10.5 \%$ of cells. Thus, even if by emptying the $\mathrm{Ca}^{2+}$ stores TG induces apoptosis in $5 \%$ of cells, our results clearly show that when TG induces a sustained increase in $\left[\mathrm{Ca}^{2+}\right]_{\mathrm{i}}$ it doubles the apoptosis level, pointing to capacitative $\mathrm{Ca}^{2+}$ entry as one of the $\mathrm{Ca}^{2+}$ events in apoptosis induction by TG in DU145 cells.

To further investigate the role of capacitative $\mathrm{Ca}^{2+}$ entry in apoptosis induction in DU145 cells, we studied the role of the amplitude of the capacitative $\mathrm{Ca}^{2+}$ influx in this phenomenon. For this, we lowered the capacitive calcium entry by readmission of $200 \mu \mathrm{M}$ $\mathrm{Ca}^{2+}$ into the extracellular medium (instead of $2 \mathrm{mM}$ ) after TG treatment made in a calcium-free medium (see Fig. 5d with $200 \mu \mathrm{M} \mathrm{Ca}{ }^{2+}$, as compared with Fig. $5 \mathrm{c}$ with $2 \mathrm{mM} \mathrm{Ca}^{2+}$ ). A decrease in the amplitude of the sustained ( 24 and $48 \mathrm{~h}$ ) $\mathrm{Ca}^{2+}$ increase was also observed (see the table in Fig. 5d as compared with the table in Fig. 5c). This treatment for $48 \mathrm{~h}$ induced apoptosis in $6.8 \%$ of cells. As reducing the extracellular calcium concentration reduces TG-induced apoptosis by about $30 \%$, it is clear that in androgenindependent DU145 PC cells the level of apoptosis induced by TG depends on the amplitude of the $\mathrm{Ca}^{2+}$ increase due to the capacitative $\mathrm{Ca}^{2+}$ influx. 
A

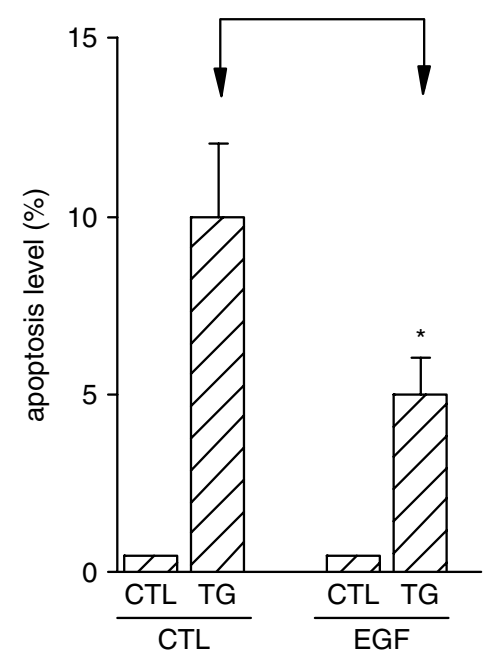

C

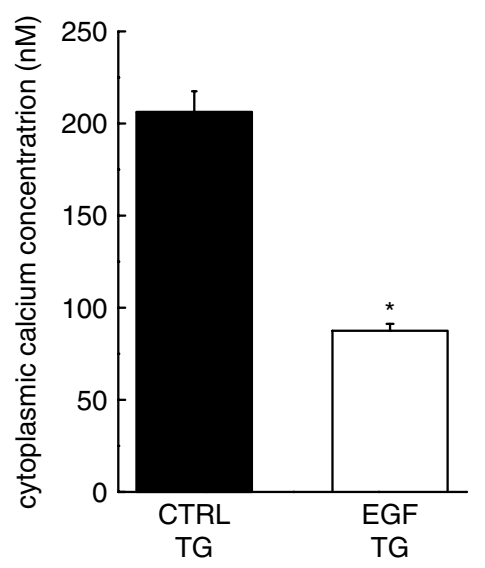

B
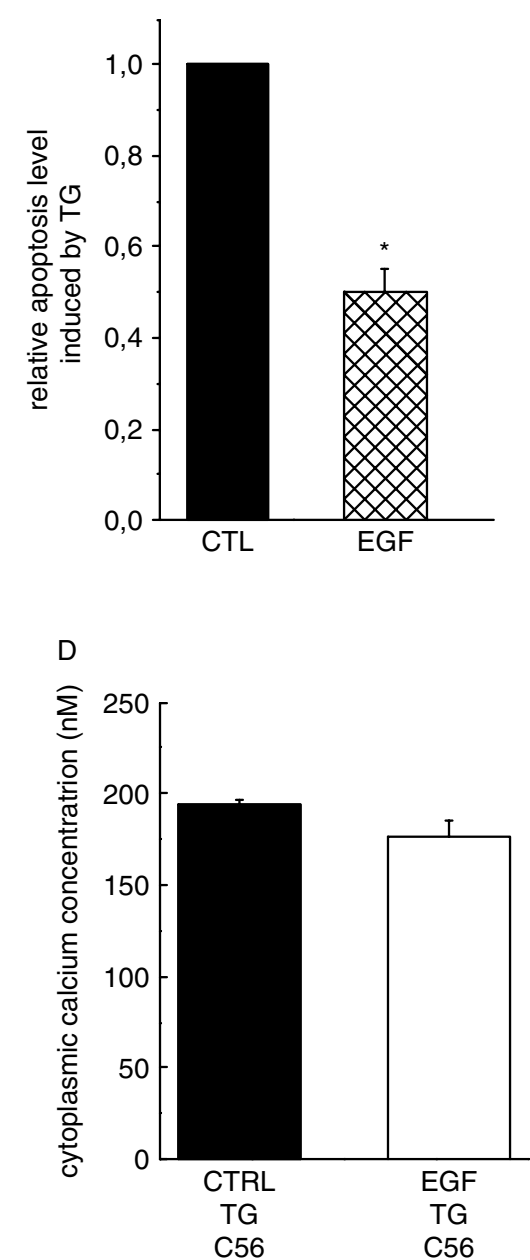

Figure 4 EGF protects DU145 cells from the TG-induced apoptosis and from the long-term cytotoxic $\mathrm{Ca}^{2 \pm}$ overload induced by TG. Cells were pretreated with $5 \mathrm{ng} / \mathrm{ml}$ EGF for $72 \mathrm{~h}$ prior the $48 \mathrm{~h} 1 \mu \mathrm{M}$ TG treatment (combined with EGF). (a) Apoptosis was labelled using the Hoechst staining method, as indicated in the Experimental procedures section. (b) Apoptosis was measured using flow cytometry. Results represent the relative level of apoptosis. Apoptosis observed in control (CTL) conditions is labelled as 1. (c) $\left[\mathrm{Ca}^{2+}\right]_{i}$ was measured after a 48-h TG $(1 \mu \mathrm{M})$ treatment in a culture medium containing 2 mM Ca ${ }^{2+}$. Experiments were performed on control cells cultured with $2 \% \mathrm{FCS}$ and on cells treated by $5 \mathrm{ng} / \mathrm{ml}$ EGF $48 \mathrm{~h}$ before the TG treatment. Note that EGF was maintained during the TG treatment. (d) $\left[\mathrm{Ca}^{2+}\right]_{\mathrm{i}}$ was measured after a $48-\mathrm{h} \mathrm{TG}(1 \mu \mathrm{M})$ treatment in a culture medium containing $2 \mathrm{mM} \mathrm{Ca}^{2+}$. Experiments were performed with $\mathrm{C} 56(15 \mathrm{pM})$ on control cells cultured with $2 \% \mathrm{FCS}$, and on cells treated with $5 \mathrm{ng} / \mathrm{ml}$ EGF $48 \mathrm{~h}$ before TG treatment. Note that EGF was maintained during TG treatment.

Finally, we studied the role of the duration of the capacitative $\mathrm{Ca}^{2+}$ entry in apoptosis induction in DU145 cells. As shown in Fig. 5c, readmission of $2 \mathrm{mM} \mathrm{Ca}^{2+}$ into extracellular media after the transient increase caused by TG in a $\mathrm{Ca}^{2+}$-free medium induced a sustained (see Fig. 5c) capacitive $\mathrm{Ca}^{2+}$ entry and apoptosis in $10 \%$ of cells within $48 \mathrm{~h}$. By removing extracellular $\mathrm{Ca}^{2+}$ at a specific time after the beginning of the capacitative $\mathrm{Ca}^{2+}$ influx (represented by $\mathrm{T}$ on
Fig. 5e), $\mathrm{Ca}^{2+}$ returned to its basal level (see Fig. 5e). In these conditions, by labelling the apoptosis level $48 \mathrm{~h}$ after the return to basal conditions, the effect of the duration of capacitative $\mathrm{Ca}^{2+}$ influx was studied. The table on Fig. 5e shows that whereas a 5- or 30-min capacitative $\mathrm{Ca}^{2+}$ influx is insufficient to increase apoptosis, as compared with calcium store mobilization alone after $48 \mathrm{~h}$ (see Fig. $5 \mathrm{a}$ and b), a 2-h $\mathrm{Ca}^{2+}$ influx induces apoptosis in $9.7 \%$ of cells after $48 \mathrm{~h}$. 
a

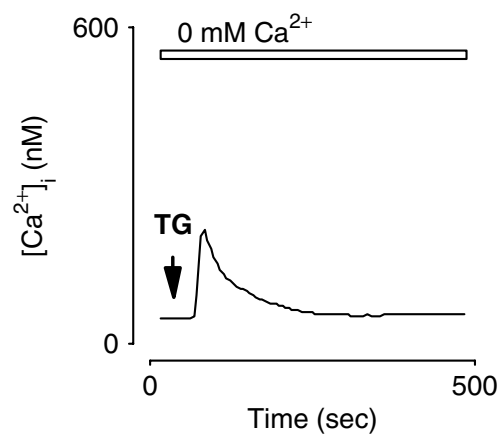

C

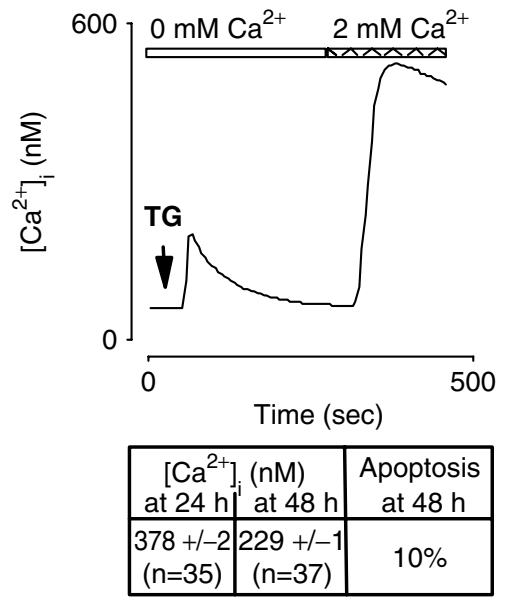

e

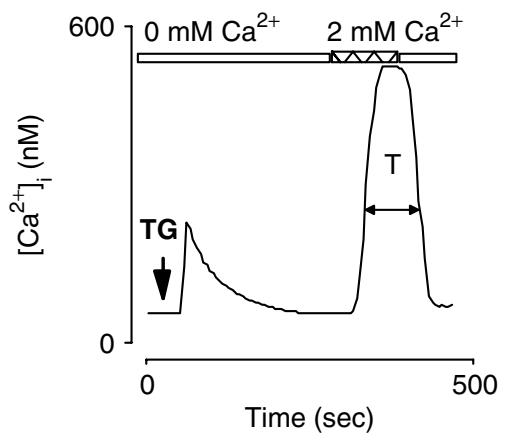

b

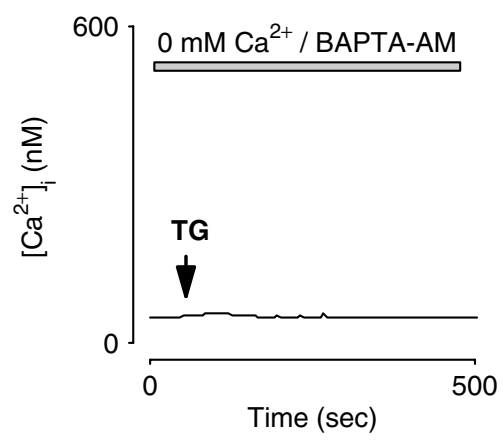

d

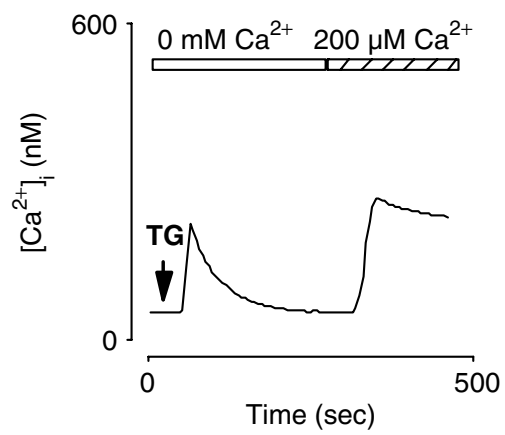

\begin{tabular}{|c|c|c|c|}
\hline$T$ & $\begin{array}{r}{\left[\mathrm{Ca}^{2+}\right]_{i}(\mathrm{nM})} \\
\text { at } 24 \text { hi }\end{array}$ & $\begin{array}{c}\text { Apoptosis } 48 \mathrm{~h} \\
\text { at 48 } \mathrm{h}\end{array}$ \\
\hline 5 min & $\begin{array}{r}61+/-2 \\
(\mathrm{n}=34)\end{array}$ & $\begin{array}{r}59+/-1 \\
(\mathrm{n}=36)\end{array}$ & $6,4 \%$ \\
\hline 30 min & $\begin{array}{r}60+/-2 \\
(\mathrm{n}=37)\end{array}$ & $\begin{array}{r}53+/-2 \\
(\mathrm{n}=36)\end{array}$ & $7,5 \%$ \\
\hline 2 hours & $\begin{array}{r}52+/-3 \\
(\mathrm{n}=31)\end{array}$ & $\begin{array}{c}56+/-2 \\
(\mathrm{n}=32)\end{array}$ & $9,7 \%$ \\
\hline 6 hours & $\begin{array}{r}62+/-2 \\
(\mathrm{n}=32)\end{array}$ & $\begin{array}{r}58+/-2 \\
(\mathrm{n}=37)\end{array}$ & $11 \%$ \\
\hline
\end{tabular}

\begin{tabular}{|c|c|c|}
\hline $\begin{array}{r}{\left[\mathrm{Ca}^{2+}\right]} \\
\text { at } 24 \mathrm{~h}\end{array}$ & \begin{tabular}{|l|}
$(\mathrm{nM})$ \\
at $48 \mathrm{~h}$ \\
\end{tabular} & $\begin{array}{c}\text { Apoptosis } \\
\text { at } 48 \mathrm{~h}\end{array}$ \\
\hline $\begin{array}{c}47+/-2 \\
(n=36)\end{array}$ & $\begin{array}{c}57+/-1 \\
(n=38)\end{array}$ & $5^{\circ}$ \\
\hline
\end{tabular}

\begin{tabular}{|c|c|c|}
\hline $\begin{array}{r}{\left[\mathrm{Ca}^{2+}\right.} \\
\text { at } 24 \mathrm{~h}\end{array}$ & $\begin{array}{l}]_{\mathrm{i}}(\mathrm{nM}) \\
\text { lat } 48 \mathrm{~h}\end{array}$ & $\begin{array}{c}\text { Apoptosis } \\
\text { at } 48 \mathrm{~h}\end{array}$ \\
\hline $\begin{array}{c}139+/-2 \\
(n=34)\end{array}$ & $\begin{array}{c}119+/-1 \\
(n=36)\end{array}$ & \\
\hline
\end{tabular}

Figure 5 Characterization of the role of $\mathrm{Ca}^{2 \pm}$ homeostasis perturbation in apoptosis induction in DU145 cells. Cells were cultured in media supplemented with $10 \%$ FCS. On the following day the medium was replaced by medium containing $2 \%$ serum supplemented with the indicated doses of $\mathrm{Ca}^{2+}$ and BAPTA-AM. Cells were treated with $1 \mu \mathrm{M}$ TG for $48 \mathrm{~h}$ in these conditions. Traces show the short-lived modifications in $\left[\mathrm{Ca}^{2+}\right]_{\mathrm{i}}$ induced by TG treatment, whereas the tables illustrate the longlasting $(24$ and $48 \mathrm{~h})$ effects of these treatments on $\left[\mathrm{Ca}^{2+}\right]_{i}$, as well as apoptosis level at $48 \mathrm{~h}$. $(\mathrm{a}, \mathrm{b}) \mathrm{Role}$ of $\mathrm{Ca}^{2+}$-store mobilization in TG-induced apoptosis. (a) Effects of TG application in a $\mathrm{Ca}^{2+}$-free medium, on $\left[\mathrm{Ca}^{2+}\right]_{i}$ and apoptosis: in a $\mathrm{Ca}^{2+}$-free medium a 48-h TG treatment induced only a short-lived increase in $\left[\mathrm{Ca}^{2+}\right]_{i}$ due to $\mathrm{Ca}^{2+}$-store mobilization without any sustained modification of $\left[\mathrm{Ca}^{2+}\right]_{\mathrm{i}}$ (see table). (b) Role of transient $\left[\mathrm{Ca}^{2+}\right]_{\mathrm{i}}$ increase due to $\mathrm{Ca}^{2+}$-store mobilization in TGinduced apoptosis: the trace shows the effect of TG application in a $\mathrm{Ca}^{2+}$-free medium supplemented with BAPTA-AM (50 $\left.\mu \mathrm{M}\right)$. In these conditions the emptying of the stores induced by TG did not modify $\left[\mathrm{Ca}^{2+}\right]_{\mathrm{i}}$. However, after $48 \mathrm{~h}$ apoptosis was induced at a similar level to that in (a). (c-e) Role of capacitive calcium entry in TG-induced apoptosis. (c) Effect of capacitative calcium entry induced by $\mathrm{TG}$ on $\left[\mathrm{Ca}^{2+}\right]_{i}$ and apoptosis: the emptying of the store induced by TG activated a sustained capacitative calcium influx measurable by readmitting $2 \mathrm{mM}$ extracellular calcium. Apoptosis was measured after a $48-\mathrm{h}$ treatment in these conditions, and the apoptosis level increased as compared with cells exposed to calcium-store mobilization alone ( $a$ and b). (d) Role of the amplitude of capacitative calcium influx in TG-induced apoptosis: by reducing the extracellular calcium concentration to $200 \mu \mathrm{M}$, both the amplitude of the sustained capacitative calcium influx and apoptosis level induced by TG were reduced (as compared with c, in $2 \mathrm{mM}$ extracellular $\mathrm{Ca}^{2+}$ ). (e) Role of the duration of the capacitative calcium influx in apoptosis induction: by removing extracellular calcium at a determined time after the beginning of the capacitative calcium influx (represented by T), calcium stably returned to the basal level. The role of the duration of capacitative calcium influx was studied by labelling apoptosis level in these conditions, $48 \mathrm{~h}$ after the return in basal cytosolic calcium concentrations. 
a
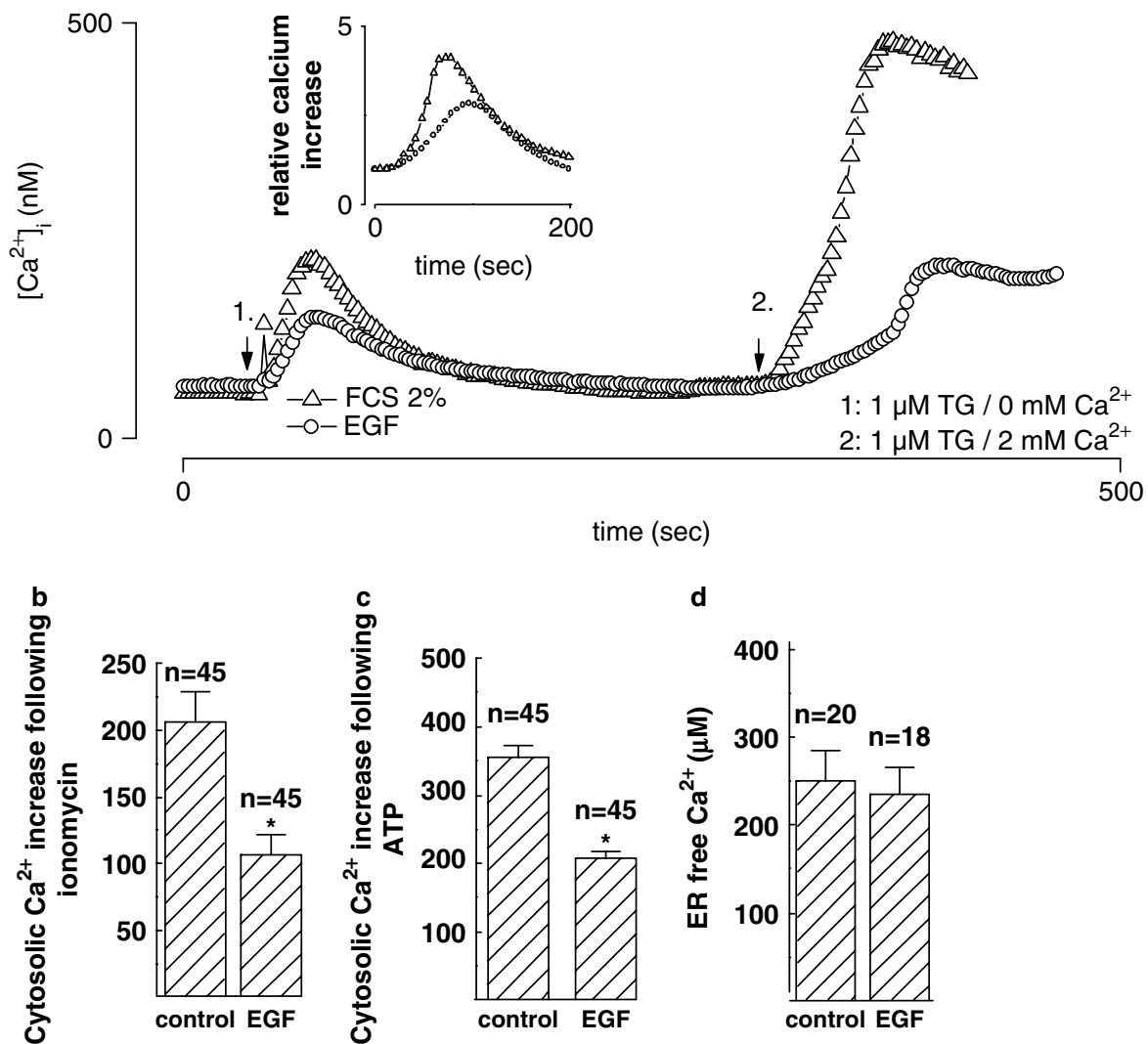

d

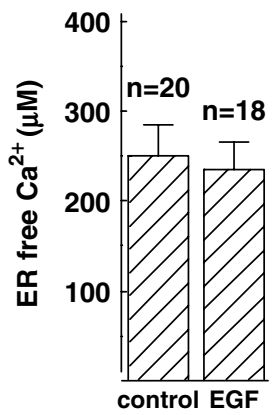

Figure 6 EGF reduced the amount and the speed of the calcium that could be released from internals stores. (a) TG was used to study the amount of $\mathrm{Ca}^{2+}$ that is releasable from the stores, as well as the corresponding capacitative $\mathrm{Ca}^{2+}$ entry. Experiments were performed on control cells ( $\{O T\})$, as well as on cells pretreated for $48 \mathrm{~h}$ with $5 \mathrm{ng} / \mathrm{ml} E G F(\{O C\})$. Insert: Typical traces showing decrease in the speed of cytosolic calcium. Calcium increase was obtained in a calcium-free medium using TG. (b) lonomycin $(1 \mu \mathrm{M})$ was used to study the amount of $\mathrm{Ca}^{2+}$ releasable from the stores in a calcium-free medium. (c) ATP $(100 \mu \mathrm{M})$ was used to study the amount of $\mathrm{Ca}^{2+}$ that is releasable form the stores in a calcium-free medium.

(d) Quantification of $\left[\mathrm{Ca}^{2+}\right]_{\mathrm{ER}}$ measured in digitonin-permeabilized cells based on Mag-fura 2 fluorescence.

Moreover, a 6-h $\mathrm{Ca}^{2+}$ influx is sufficient to induce maximal apoptosis levels after $48 \mathrm{~h}$ (as compared with the apoptosis induced by the 48-h sustained capacitative $\mathrm{Ca}^{2+}$ influx shown in Fig. 5c). Finally we showed that NED by itself is not linked to a variation in the basal cytoplasmic calcium since the amount of the resting cytoplasmic calcium measured in nontreated cells was not significantly modified following NED and was $54 \pm 9 \mathrm{nM}(n=85)$.

Taken together, these results show that in androgenindependent DU145 PC cells the depletion of intracellular $\mathrm{Ca}^{2+}$ store may induce apoptosis, and that apoptosis is increased in cells where capacitative $\mathrm{Ca}^{2+}$ entry is induced, pointing to capacitative $\mathrm{Ca}^{2+}$ influx as one of the events in the phenomenon of apoptosis induction. Moreover, our results provide the first evidence that in androgen-independent PC cells the amplitude and the duration of capacitative $\mathrm{Ca}^{2+}$ entry are two parameters that control apoptosis.

\section{NED of androgen-independent prostatic cells reduces the $\mathrm{Ca}^{2+}$ released from intracellular pools and the following capacitative $\mathrm{Ca}^{2+}$ entry}

As our results demonstrated how the $\mathrm{Ca}^{2+}$ signal induces apoptosis in DU145 cells, we investigated the effect of NED on DU145 $\mathrm{Ca}^{2+}$ homeostasis. ER Ca ${ }^{2+}$ release was thus estimated by measuring the difference between basal $\left[\mathrm{Ca}^{2+}\right]_{\mathrm{i}}$ and $\mathrm{Ca}^{2+}$ peaks induced by TG in a $\mathrm{Ca}^{2+}$-free medium. Our results show that NED is associated with a reduction in the amount of $\mathrm{Ca}^{2+}$ that can be released from the ER (Fig. 6). Indeed, in control conditions, the release induced by $1 \mu \mathrm{M}$ TG application 
reached $210 \pm 5 \mathrm{nM} \quad(n=54)$, whereas this release reached $159 \pm 10 \mathrm{nM}(n=32)$ in neuroendocrinedifferentiated cells, corresponding to $76 \%$ of the amount released in control conditions (Fig. 6a). The speed of the calcium release induced by $\mathrm{TG}$ also decreased. In effect, calcium release induced by TG was $0.12 \pm 0.01 \mathrm{nM} / \mathrm{s}(n=90)$ when cells were differentiated with EGF while it was $0.53 \pm 0.08 \mathrm{nM} / \mathrm{s}$ $(n=90)$ in control conditions.

To confirm the reduction in the amount of calcium that can be released from internal stores we measured the calcium release induced by ionomycin $(1 \mu \mathrm{M})$ or by activating purinergic receptors with ATP $(100 \mu \mathrm{M})$ as already described in DU145 cells (Fang et al. 1992). As depicted in Fig. 6b and c, the calcium that can be released by ionomycin or by ATP was reduced in neuroendocrine-differentiated cells. Indeed the calcium release was reduced by 49 and $41 \%$ when cells were challenged with ionomycin and ATP respectively. In comparison the level of free $\left[\mathrm{Ca}^{2+}\right]$ in the reticulum and measured with Mag-fura 2 was not modified after NED (Fig. 6d).

Our results also show that NED affects the capacitative $\mathrm{Ca}^{2+}$ entry observed after readmitting extracellular $\mathrm{Ca}^{2+}$. Indeed, the amplitude of capacitative $\mathrm{Ca}^{2+}$ entry induced by $1 \mu \mathrm{M}$ TG application in control conditions reached $477 \pm 12 \mathrm{nM} \quad(n=54)$, whereas it reached $235 \pm 22 \mathrm{nM}(n=32)$ in neuroendocrinedifferentiated cells. Thus, NED is correlated with a reduction of the amplitude of $\mathrm{Ca}^{2+}$ entry and the amplitude of entry corresponded to $49 \%$ of the control $\mathrm{Ca}^{2+}$ entry.

The results presented in this study demonstrate for the first time the ability of androgen-independent cells to undergo NED following a growth factor treatment. In addition, we demonstrate the role of the calciumsignal amplitude and duration in the induction of apoptosis in androgen-independent cell line. Furthermore, we show that a depression in calcium homeostasis confers apoptosis resistance on the neuroendocrinedifferentiated DU145 cells.

\section{Discussion}

\section{EGF treatment induced NED in androgen- independent prostate cancerous cell line}

To date, the mechanism leading to the development of the neuroendocrine cell population in advanced tumours is poorly understood. It has been described that androgen-sensitive cell lines have the ability to transdifferentiate into cells with a neuroendocrine-like phenotype. It has been also demonstrated that neuroendocrine cells lack nuclear androgen receptor and thus represent an androgen-insensitive cell phenotype in the prostate (Krijnen et al. 1993). This absence of androgen receptor in neuroendocrine tumour cells suggests that these cells may represent a population that could initially be androgen-independent and therefore refractory to androgen-deprivation therapy. Here we show, for the first time, that androgenindependent DU145 cells have the ability to transdifferentiate. After this treatment, differentiated DU145 exhibit a significant level of morphological changes that were similar to descriptions in the literature of PC cells undergoing differentiation towards neuroendocrine phenotypes (Bang et al. 1994). Furthermore, we show that expression of NSE increases when cells are treated with EGF. Increase in NSE expression is a marker that has been used previously to assess differentiation of $\mathrm{LNCaP}$ cells (Mori et al. 1999). Taken together our results demonstrate that EGF has the ability to induce NED of DU145 cells.

It has been previously established that NED of prostate cells, including androgen-independent ones, can be induced by agents that increase cAMP (Zelivianski et al. 2001). Here, we show that these agents (db-cAMP and IBMX) were ineffective by themselves to promote NED of androgen-independent DU145 cells. However, db-cAMP and IBMX increased the efficiency of EGF in inducing NED.

The NED process has itself been suggested to induce cell-cycle arrest (Mori et al. 1999, Blutt et al. 1997). Here we show that NED induced by EGF (between 1.6 and $6.2 \mathrm{ng} / \mathrm{ml}$ ) is correlated with a reduction in cell proliferation. This reduction of the proliferation rate was moderate $(20 \%)$. This decrease in cell growth observed with EGF is surprising, since exogenous EGF has already been described as having little effect on cell growth when they are cultured at high densities, because the amount of EGF being secreted by DU145 is sufficient for optimal stimulation by EGF (Connolly \& Rose 1991). In this study one may consider the fact that the additional doses of EGF considerably increase the level of EGF in our culture conditions at a doses rendering EGF able to reduce cell growth.

It has been demonstrated that the micro-environement is likely to play a critical role in growth and to control phenotypic properties of prostatic tumours (Cunha 1994, Chung 1995). Here we show that NED of androgen-independent cells is specifically induced by EGF, which is a growth factor that has been frequently been implicated in PC progression (Barton et al. 2001). This function of EGF in PC cells was unexpected. Such an 
effect of EGF is mediated by EGF activation of a tyrosine kinase pathway since this was not observed when genistein was used. Activation of EGFR by heparin-binding EGF-like growth factor has been demonstrated to stimulate NED in LNCaP cells linked to STAT3 phosphorylation (Kim et al. 2002). Nevertheless, to date no effect of EGF on NED in LNCaP cells has been reported.

In this study, we identify an unrecognized function for EGF in androgen-independent DU145 cells, as a mediator of NED. We suggest that this growth factor could be a key signal linked to NED in androgenindependent prostate cell.

\section{NED induced by EGF protects DU145 cells from the TG-induced apoptosis}

Our data show that TG induces apoptosis in about $10 \%$ of androgen-independent DU145 PC cells. This result is in accordance with studies demonstrating that an increase in $\left[\mathrm{Ca}^{2+}\right]_{\mathrm{i}}$ induced by $\mathrm{TG}$ induced apoptosis (Orrenius et al. 2003). Nevertheless, levels of apoptosis observed in our study are significantly lower than the ones previously observed in the same cell type by other authors (He et al. 2002). However, this low apoptosis level, observed in our experimental conditions, reflects the fact that androgen-independent cells are resistant to apoptosis when compared with androgen-dependent ones (Prevarskaya et al. 2004). Our experiments also show that pre-treatment with EGF before a $48 \mathrm{~h}$ treatment by $1 \mu \mathrm{M}$ TG reduces the level of the TG-induced apoptosis by $48 \%$. Indeed, we demonstrate that NED of androgen-independent cells is a mechanism by which prostate cells can escape apoptosis. Our results are in accordance with those describing how neuroendocrine tumour cells escape apoptotic cell death (Fixemer et al. 2002, Vanoverberghe et al. 2004) and that EGF protects several cell types, including prostate cells, from apoptosis (Mimeault et al. 2003).

\section{Calcium signalling and induction of apoptosis in DU145 cells}

To understand how the NED of androgen-independent human PC cells protects them from apoptosis due to calcium overload we first investigated the role of $\mathrm{Ca}^{2+}$ homeostasis in the apoptotic regulation of DU145 cell. At that time, two hypotheses were proposed about the role of $\mathrm{Ca}^{2+}$ in apoptosis induction. The first assumed that apoptosis may be triggered by $\mathrm{ER} \mathrm{Ca}^{2+}$-pool depletion without any requirement for cytosolic $\mathrm{Ca}^{2+}$ elevation due to store-operated $\mathrm{Ca}^{2+}$ entry (Bian et al. 1997, He et al. 1997). The second hypothesis, on the contrary, assumed that a sustained elevation of cytosolic $\mathrm{Ca}^{2+}$ to a critical level is the initiator of apoptosis (Dowd et al. 1992, Wang et al. 1999). In prostate cells, these two opposing hypotheses have already been reported (Prevarskaya et al. 2004). Indeed, studies performed in our laboratory demonstrate that in human androgen-dependent LNCaP PC cells the depletion of intracellular $\mathrm{Ca}^{2+}$ stores may trigger apoptosis without any requirement for a sustained $\mathrm{Ca}^{2+}$ entry (Skryma et al. 2000). On the other hand, $\mathrm{Ca}^{2+}$ pool depletion appears insufficient to initiate apoptosis in rat androgen-independent PC cells. Indeed, Furuya et al. (1994) reported that in rat androgen-independent PC AT3 cells programmed cell death is critically dependent on an adequate (i.e. 3-4 fold) sustained $(>1 \mathrm{~h})$ elevation in $\left[\mathrm{Ca}^{2+}\right]_{i}$ and not on depletion of the ER $\mathrm{Ca}^{2+}$ pools.

We show that in DU145 cells apoptosis can be induced by $\mathrm{ER} \mathrm{Ca}^{2+}$ pool depletion alone, without any requirement for a cytosolic $\left[\mathrm{Ca}^{2+}\right]$ increase. Furthermore, our data clearly demonstrate that when $\mathrm{Ca}^{2+}$ depletion is followed by a $\mathrm{Ca}^{2+}$ entry from extracellular medium apoptosis is amplified. Our results further demonstrate that the level of apoptosis is proportional to the level and the duration of the $\mathrm{Ca}^{2+}$ increase. Thus the amplitude and kinetics of the $\mathrm{Ca}^{2+}$ signal appear to be crucial regulators of apoptosis in DU145 PC cells. This result is of a great interest since it points out a fundamental difference between $\mathrm{Ca}^{2+}$ regulation of apoptosis in two major PC cell lines: androgen-dependent $\mathrm{LNCaP}$ PC cells and androgen-independent DU145 PC cells. Indeed, in our previous study, we showed that in an androgendependent PC cell line a decrease in the ER $\mathrm{Ca}^{2+}$ pool is a major factor in apoptosis induction, and that the following $\mathrm{Ca}^{2+}$ influx is not needed for the apoptosis phenomenon to occur (Skryma et al. 2000). Our results show that independently of the $\mathrm{Ca}^{2+}$ level the depletion of $\mathrm{Ca}^{2+}$ stores may induce apoptosis in DU145 cells. This result is not surprising, since the maintenance of sufficient levels of $\mathrm{Ca}^{2+}$ within the ER is essential not only for $\mathrm{Ca}^{2+}$ signal transduction, but also for protein synthesis and processing, and cell proliferation (Koch 1990, Sambrook 1990, Jiang \& Julian 1998). Moreover, mechanisms by which ER depletion might contribute to apoptosis without any $\left[\mathrm{Ca}^{2+}\right]_{\mathrm{i}}$ increase have been reported by He et al. (2002): (i) depletion of the $\mathrm{ER} \mathrm{Ca}^{2+}$ pools might destabilize the $\mathrm{Ca}^{2+}$-protein gel and its associated membrane, leading to vesiculation and the formation of apoptotic blebs, (ii) disruption of protein processing and transport within the ER may contribute to TG-induced apoptosis and (iii) TG-induced $\mathrm{ER} \mathrm{Ca}^{2+}$ pools 
depletion releases an endonuclease into the nucleus responsible for DNA fragmentation. Moreover, alternative mechanisms include the activation of caspase 12 which can be directly stimulated by depletion of the $\mathrm{ER} \mathrm{Ca}^{2+}$ pool (McConkey \& Nutt 2001).

Our results are the first which describe calciumdependent apoptosis in androgen-independent PC cells. In effect, it has been recently demonstrated the TSU-PR1 cell line originally described as human androgen-independent $\mathrm{PC}$ cells and requiring $\mathrm{Ca}^{2+}$ entry for apoptosis in fact derives from T24 bladder carcinoma cells (van Bokhoven et al. 2001).

\section{Apoptosis resistance of neuroendocrine- differentiated DU145 cells is conferred by modifications in the calcium homeostasis}

Since we demonstrated the involvement of $\mathrm{Ca}^{2+}$ homeostasis perturbation in apoptosis induction in DU145 cells, we investigated the effect of NED on $\mathrm{Ca}^{2+}$ homeostasis. Our results failed to demonstrate any effect of NED on basal cytosolic $\left[\mathrm{Ca}^{2+}\right]$ or on the level of endoplasmic free calcium. By contrast, a reduction in the amount of calcium that can be released from the ER was observed following NED as well as capacitative calcium entry. This result clearly explains how neuroendocrine-differentiated cells become resistant to apoptosis, since we demonstrated that in DU145 cells the apoptosis level is proportionally dependent on the amplitude of $\mathrm{Ca}^{2+}$ increase induced by apoptotic signal. Thus the reduction of both the amount of $\mathrm{Ca}^{2+}$ that can be released from the stores and the subsequent $\mathrm{Ca}^{2+}$ entry into neuroendocrine-differentiated cells can account for the apoptosis resistance of neuroendocrine-differentiated cells. Such a prevention of apoptosis by a control calcium homeostasis has already been reported in mesangial cells, where a sustained increase in the $\left[\mathrm{Ca}^{2+}\right]_{\mathrm{i}}$ that triggers apoptosis was thwarted by platelet-derived growth factor (Saleh et al. 2000). More recently, reduction of the expression of inositol 1,4,5-trisphosphate receptor type 1 in cisplatin-resistant cells has also been demonstrated, pointing out that regulation of the calcium signalplex is important to cancer progression and resistance to treatments (Tsunoda et al. 2005). In addition, a reduction in the calcium signalling (i.e reduction of the calcium release and the calcium influx) has also been described as the mechanism leading to apoptosis resistance of PC cells (Prevarskaya et al. 2004, Vanoverberghe et al. 2004). In effect, apoptosis resistance conferred by NED in $\mathrm{LNCaP}$ cells was accompanied by a reduction in both calcium release and calcium entry (Vanoverberghe et al. 2004). Thus, the reduction in the calcium signal caused by neuroendocrine-differentiated PC cells is a common mechanism that leads to the apoptosis resistance of PC cells besides an increase in survivin and clusterin (Xing et al. 2001, July et al. 2002).

These results highlight a new emergence path for neuroendocrine cells in prostate malignancy by demonstrating the neuroendocrine differentiating effect of EGF. Furthermore, we describe the reduction in the calcium signalling as being a common way inducing apoptosis resistance in neuroendocrinedifferentiated PC cells. Our results suggest that targeting EGF and its receptor as well as calcium homeostasis in an attempt to enhance the proapoptotic potential of malignant cells may be a useful strategy in the treatment of advanced PC.

\section{Acknowledgements}

This work was supported by grants from INSERM (Institut National de la Santé et de la Recherche Médicale), ARC (Association pour la Recherche sur le Cancer) and ARTP (Association pour la Recherche sur les Tumeurs de la Prostate). The authors would like to thank Etienne Dewailly and Phillippe Marchetti for their technical assistance. The authors declare that there is no conflict of interest that would prejudice the impartiality of this scientific work.

\section{References}

Abrahamsson PA 1999 Neuroendocrine cells in tumor growth of the prostate. Endocrine Related Cancer 6 503-519.

Aumuller G, Leonhardt M, Janssen M, Konrad L, Bjartell A \& Abrahamsson PA 1999 Neurogenic origin of human prostate endocrine cells. Urology 53 1041-1048.

Bang YJ, Pirnia F, Fang WG, Kang WK, Sartor O, Whitesell L, Ha MJ, Tsokos M, Sheahan MD \& Nguyen P 1994 Terminal neuroendocrine differentiation of human prostate carcinoma cells in response to increased intracellular cyclic AMP. PNAS 91 5330-5334.

Barton J, Blackledge G \& Wakeling A 2001 Growth factors and their receptors: new targets for prostate cancer therapy. Urology 58 114-122.

Bian X, Hughes FM Jr, Huang Y, Cidlowski JA \& Putney JW 1997 Roles of cytoplasmic $\mathrm{Ca}^{2+}$ and intracellular $\mathrm{Ca}^{2+}$ stores in induction and suppression of apoptosis in S49 cells. American Journal of Physiology Cell Physiology 272 C1241-C1249.

Blutt SE, Allegretto EA, Pike JW \& Weigel NL 1997 1,25-Dihydroxyvitamin D3 and 9-cis-retinoic acid act synergistically to inhibit the growth of LNCaP prostate cells and cause accumulation of cells in G1. Endocrinology 138 1491-1497. 
Bonkhoff H \& Remberger K 1996 Differentiation pathways and histogenetic aspects of normal and abnormal prostatic growth: a stem cell model. Prostate 28 98-106.

Burchardt T, Burchardt M, Chen MW, Cao Y, de la Taille A, Shabsigh A, Hayek O, Dorai T \& Buttyan R 1999 Transdifferentiation of prostate cancer cells to a neuroendocrine cell phenotype in vitro and in vivo. Journal of Urology 162 1800-1805.

Chung LW 1995 The role of stromal-epithelial interaction in normal and malignant growth. Cancer Surveys $\mathbf{2 3}$ 33-42.

Connolly JM \& Rose DP 1991 Autocrine regulation of DU145 human prostate cancer cell growth by epidermal growth factor-related polypeptides. Prostate 19 173-180.

Cox ME, Deeble PD, Bissonette EA \& Parsons SJ 2000 Activated $3^{\prime}, 5^{\prime}$-cyclic AMP-dependent protein kinase is sufficient to induce neuroendocrine-like differentiation of the LNCaP prostate tumor cell line. Journal of Biological Chemistry 275 13812-13818.

Crawford ED 1989 Combined androgen blockade. Urology 34 22-26.

Cunha GR 1994 Role of mesenchymal-epithelial interactions in normal and abnormal development of the mammary gland and prostate. Cancer 74 1030-1044.

Cussenot O, Villette JM, Cochand-Priollet B \& Berthon P 1998 Evaluation and clinical value of neuroendocrine differentiation in human prostatic tumors. Prostate Supplement 8 43-51.

Denmeade SR, Lin XS \& Isaacs JT 1996 Role of programmed (apoptotic) cell death during the progression and therapy for prostate cancer. Prostate 28 251-265.

Dowd DR, MacDonald PN, Komm BS, Haussler MR \& Miesfeld RL 1992 Stable expression of the calbindinD28K complementary DNA interferes with the apoptotic pathway in lymphocytes. Molecular Endocrinology 6 1843-1848.

Fang WG, Pirnia F, Bang YJ, Myers CE \& Trepel JB 1992 $\mathrm{P} 2$-purinergic receptor agonists inhibit the growth of androgen-independent prostate carcinoma cells. Journal of Clinical Investigation 89 191-196.

Fixemer T, Remberger K \& Bonkhoff H 2002 Apoptosis resistance of neuroendocrine phenotypes in prostatic adenocarcinoma. Prostate 53 118-123.

Furuya Y, Lundmo P, Short AD, Gill DL \& Isaacs JT 1994 The role of calcium, $\mathrm{pH}$, and cell proliferation in the programmed (apoptotic) death of androgen-independent prostatic cancer cells induced by thapsigargin. Cancer Research 54 6167-6175.

Grobholz R, Griebe M, Sauer CG, Michel MS, Trojan L \& Bleyl U 2005 Influence of neuroendocrine tumor cells on proliferation in prostatic carcinoma. Human Pathology $36562-570$.

Grynkiewicz R, Poenie M \& Tsien RY 1985 A new generation of $\mathrm{Ca}^{2+}$ indicators with greatly improved fluorescence properties. Journal of Biological Chemistry 260 3440-3450.
He H, Lam M, McCormick TS \& Distelhorst CW 1997 Maintenance of calcium homeostasis in the endoplasmic reticulum by Bcl-2. Journal of Cell Biology 138 1219-1228.

He Q, Lee DI, Rong R, Yu M, Luo X, Klein M, El-Deiry WS, Huang Y, Hussain A \& Sheikh MS 2002 Endoplasmic reticulum calcium pool depletion-induced apoptosis is coupled with activation of the death receptor 5 pathway. Oncogene 21 2623-2633.

Humez S, Monet M, van Coppenolle F, Delcourt P \& Prevarskaya N 2004a The role of intracellular pH in cell growth arrest induced by ATP. American Journal of Physiology Cell Physiology 287 C1733-C1746.

Humez S, Legrand G, Vanden-Abeele F, Monet M, Marchetti P, Lepage G, Crepin A, Dewailly E, Wuytack F \& Prevarskaya N $2004 b$ Role of endoplasmic reticulum calcium content in prostate cancer cell growth regulation by IGF and TNFalpha. Journal of Cellular Physiology 201 201-213.

Jiang Y \& Julian FJ 1998 Effects of isoflurane on $\left[\mathrm{Ca}^{2+}\right]$ i, SR $\mathrm{Ca}^{2+}$ content, and twitch force in intact trabeculae. American Journal of Physiology Heart and Circulatory Physiology 275 H1360-H1369.

Jongsma J, Oomen MH, Noordzij MA, Van Weerden WM, Martens GJ, van der Kwast TH, Schroder FH \& van Steenbrugge GJ 1999 Kinetics of neuroendocrine differentiation in an androgen-dependent human prostate xenograft model. American Journal of Pathology 154 543-551.

July LV, Akbari M, Zellweger T, Jones EC, Goldenberg SL \& Gleave ME 2002 Clusterin expression is significantly enhanced in prostate cancer cells following androgen withdrawal therapy. Prostate 50 179-188.

Kim J, Adam RM \& Freeman MR 2002 Activation of the Erk mitogen-activated protein kinase pathway stimulates neuroendocrine differentiation in LNCaP cells independently of cell cycle withdrawal and STAT3 phosphorylation. Cancer Research 62 1549-1554.

Koch GL 1990 The endoplasmic reticulum and calcium storage. Bioessays 12 527-531.

Krijnen JL, Janssen PJ, Ruizeveld de Winter JA, van Krimpen H, Schroder FH \& van der Kwast TH 1993 Do neuroendocrine cells in human prostate cancer express androgen receptor? Histochemistry 100 393-398.

Kyprianou N, English HF \& Isaacs J 1990 Programmed cell death during regression of PC-82 human prostate cancer following androgen ablation. Cancer Research 50 3748-3753.

Landis SH, Murray T, Bolden S \& Wingo PA 1998 Cancer statistics. CA A Cancer Journal for Clinicians 48 6-29.

Mariot P, Vanoverberghe K, Lalevee N, Rossier MF \& Prevarskaya N 2002 Overexpression of an alpha $1 \mathrm{H}$ (Cav3.2) T-type calcium channel during neuroendocrine differentiation of human prostate cancer cells. Journal of Biological Chemistry 277 10824-10833.

McConkey DJ \& Nutt LK 2001 Calcium flux measurements in apoptosis. Methods in Cell Biology 66 229-246. 
Mimeault M, Pommery N \& Henichart JP 2003 New advances on prostate carcinogenesis and therapies: involvement of EGF-EGFR transduction system. Growth Factors 21 1-14.

Mori S, Murakami-Mori K \& Bonavida B 1999 Interleukin-6 induces G1 arrest through induction of p27(Kip1), a cyclin-dependent kinase inhibitor, and neuron-like morphology in LNCaP prostate tumor cells. Biochemical and Biophysical Research Communications 257 609-664.

Orrenius S, Zhivotovsky B \& Nicotera P 2003 Regulation of cell death: the calcium-apoptosis link. Nature Reviews Molecular Cell Biology 4 552-565.

Prevarskaya N, Skryma R \& Shuba Y $2004 \mathrm{Ca}^{2+}$ homeostasis in apoptotic resistance of prostate cancer cells. Biochemical and Biophysical Research Communications 322 1326-1335.

Saleh H, Schlatter E, Lang D, Pauels HG \& Heidenreich S 2000 Regulation of mesangial cell apoptosis and proliferation by intracellular $\mathrm{Ca}^{2+}$ signals. Kidney International 58 1876-1884.

Sambrook JF 1990 The involvement of calcium in transport of secretory proteins from the endoplasmic reticulum. Cell 61 197-199.

Skryma R, Mariot P, Bourhis XL, Coppenolle FV, Shuba Y, Abeele FV, Legrand G, Humez S, Boilly B \& Prevarskaya N 2000 Store depletion and store-operated $\mathrm{Ca}^{2+}$ current in human prostate cancer LNCaP cells: involvement in apoptosis. Journal of Physiology 527 71-83.

Tsunoda T, Koga H, Yokomizo A, Tatsugami K, Eto M, Inokuchi J, Hirata A, Masuda K, Okumura K \& Naito S 2005 Inositol 1,4,5-trisphosphate $\left(\mathrm{IP}_{3}\right)$ receptor type1 $\left(\mathrm{IP}_{3} \mathrm{R} 1\right)$ modulates the acquisition of cisplatin resistance in bladder cancer cell lines. Oncogene $\mathbf{2 4}$ 1396-1402.

van Bokhoven A, Varella-Garcia M, Korch C \& Miller GJ 2001 TSU-Pr1 and JCA-1 cells are derivatives of T24 bladder carcinoma cells and are not of prostatic origin. Cancer Research 61 6340-6344.

Vanoverberghe K, Vanden Abeele F, Mariot P, Lepage G, Roudbaraki M, Bonnal JL, Mauroy B, Shuba Y, Skryma R \& Prevarskaya N $2004 \mathrm{Ca}^{2+}$ homeostasis and apoptotic resistance of neuroendocrine differentiated prostate cancer cells. Cell Death and Differentiation 11 321-330.

Vashchenko N \& Abrahamsson PA 2005 Neuroendocrine differentiation in prostate cancer: implications for new treatment modalities. European Urology 47 147-155.

Wang HG, Pathan N, Ethell IM, Krajewski S, Yamaguchi Y, Shibasaki F, McKeon F, Bobo T, Franke TF \& Reed JC $1999 \mathrm{Ca}^{2+}$-induced apoptosis through calcineurin dephosphorylation of BAD. Science 284 339-343.

Xing N, Qian J, Bostwick D, Bergstralh E \& Young CY 2001 Neuroendocrine cells in human prostate over-express the anti-apoptosis protein survivin. Prostate 48 7-15.

Zamzami N, Marchetti P, Castedo M, Decaudin D, Macho A, Hirsch T, Susin SA, Petit PX, Mignotte B \& Kroemer G 1995 Sequential reduction of mitochondrial transmembrane potential and generation of reactive oxygen species in early programmed cell death. Journal of Experimental Medicine 182 367-377.

Zelivianski S, Verni M, Moore C, Kondrikov D, Taylor R \& Lin MF 2001 Multipathways for transdifferentiation of human prostate cancer cells into neuroendocrine-like phenotype. Biochimica et Biophysica Acta 1539 28-43. 
